\title{
Efficient removal of cadmium(II) with SBA-15 nanoporous silica: studies on equilibrium, isotherm, kinetics and thermodynamics
}

\author{
Qing-Zhou Zhai ${ }^{1} \cdot$ Xiao-Dong $\mathrm{Li}^{2}$
}

Received: 5 February 2019 / Accepted: 28 June 2019 / Published online: 10 July 2019

(c) The Author(s) 2019

\begin{abstract}
Nanomesoporous silica SBA-15 was prepared by hydrothermal method. The samples were characterized by powder X-ray diffraction and scanning electron microscopy. The fibrous particles with a diameter of $333 \pm 10 \mathrm{~nm}$ were obtained. Nanoporous mesoporous SBA-15 was used as an adsorbent to adsorb $\mathrm{Cd}^{2+}$ in water body. The effects of conditions such as acidity were studied, and the optimized adsorption conditions were obtained. The results showed that when the $\mathrm{pH}$ value was 5.0, the temperature was $25 \pm 1{ }^{\circ} \mathrm{C}$ and the adsorption time was $40 \mathrm{~min}$, the nanomesoporous SBA-15 had the best adsorption effect for $\mathrm{Cd}^{2+}$ and the adsorption rate was reached $73.28 \%$ and the adsorption capacity was $9.84 \mathrm{mg} / \mathrm{g}$. Study found that the adsorption is the quasi-second-order kinetic model, which belongs to the Freundlich adsorption type. The results of adsorption thermodynamics showed that when the temperature is $25-55^{\circ} \mathrm{C}$, the adsorption is spontaneous exothermic reaction, $\Delta G^{0}<0$, the adsorption enthalpy change $\Delta H^{0}=-54.732 \mathrm{~kJ} / \mathrm{mol}$, the adsorption entropy change $\Delta S^{0}=-129.343 \mathrm{~J} /(\mathrm{mol} \mathrm{K})$. The effects of nitric acid and hydrochloric acid on desorption were investigated, respectively. The results showed that the desorption effect of $0.1 \mathrm{~mol} / \mathrm{L}$ nitric acid as desorbent was better than that of hydrochloric acid. At desorption for $10 \mathrm{~h}$, the desorption rate was the highest, reaching $65.56 \%$.
\end{abstract}

Keywords Cadmium $\cdot$ Adsorption $\cdot$ SBA-15 $\cdot$ Desorption $\cdot$ Kinetics $\cdot$ Thermodynamics

\section{Introduction}

With the rapid development of economy and society, more and more events on environmental pollution have aroused great concern in the whole society. A large number of pollutants, such as heavy metals, have been discharged into the water circulation system. Among them, cadmium compounds have become the main pollution source of heavy metal pollution in industry. Chemical, iron and steel, leather, electroplating, metal smelting and processing industries will produce a large amount of divalent cadmium. The toxicity of cadmium is great, the air and food polluted by cadmium

Qing-Zhou Zhai

zhaiqingzhou5@163.com; zhaiqz@ cust.edu.cn

Xiao-Dong Li

rcnrcn1@163.com

1 Research Center for Nanotechnology, South Campus, Changchun University of Science and Technology, 7186 Weixing Road, Changchun 130022, Jilin Province, China

2 Department of Basic Science, Jilin Jianzhu University, 5088 Xincheng Street, Changchun 130118, Jilin Province, China are harmful to human body, and the metabolism is slower in human body (Zhang 1997). A large number of studies have shown that industrial wastewater containing cadmium can be effectively treated by ion exchange, polymer membrane separation, chemical reduction, electrolysis and distillation electrodialysis method. Many methods have been successfully applied to environmental protection technology and have remarkable effect. However, a large number of secondary pollution and by-products still become a thorny problem (Che 1993; Deng et al. 2005; Li et al. 1994). After the industrial heavy metal wastewater enters the domestic water system, it is difficult to remove the free ions of low concentration heavy metals. As a traditional treatment of water pollution, adsorption method has been paid attention to, but the physical and chemical properties of adsorbent affect the adsorption effect of heavy metal ions. The traditional activated carbon is expensive in cost (Clifford et al. 1986) and complex in regeneration, so it is not suitable for wastewater treatment of high concentration pollutants.

Mesoporous material (Dai et al. 2001; Jiang et al. 2003; Lin et al. 2003, Liu et al. 2004; Zhu et al. 2001), as a new burgeoning class of materials with wide application 
prospects, has potential applications in the field of research such as in separation, purification, nanoreactor, sensing devices, chemical synthesis and catalysts, energy, light, electricity and magnetic materials. It has the characteristics of quite high specific surface area, low relative density, high porosity, continuous adjustable pore size in a certain range and good hydrothermal stability. The limitation of pore size deficiency of microporous zeolite molecular sieve was overcome. It can adsorb pollutants more effectively, which can be used in environmental purification, adsorption catalysis and other fields. As an adsorbent (Pananyotova 2000), the surface area of microporous material is smaller and the adsorption effect is not ideal. Nanomesoporous material not only plays a role in catalytic reactions such as macromolecular adsorption, but also it is a good adsorbent for heavy metals, which has been used in the adsorption of $\mathrm{Pb}(\mathrm{II}), \mathrm{Ni}$ (II) ion (Ghorbani et al. 2016) and Cu(II) ion (Dana and Sayari 2011). As a nanomesoporous adsorption material, SBA-15 (Zhai et al. 2013) has large specific surface area and high adsorption capacity and it has obvious adsorption effect without adding any chemical reagents. Therefore, using SBA-15 to adsorb $\mathrm{Cd}^{2+}$ in aqueous phase has the advantages of high efficiency, high speed, strong adaptability and easy operation. Other treatment methods introduce other substances, the operations are complex, the efficiencies are low, and the costs are high.

\section{Experimental}

\section{Materials and method}

\section{Chemicals used}

1. Synthetic reagents for SBA-15

Template tri-block copolymer poly(ethylene glycol)-blockpoly(propylene glycol)-block-poly (ethylene glycol] (P123, average molecular weight 5800, Aldrich), tetraethylorthosilicate (TEOS, The First Plant of Reagents of Shanghai City, China), hydrochloric acid (Beijing Chemical Plant, China).

2. Reagents for the adsorption of cadmium(II) by SBA-15

Cadmium chloride (Shanghai Jinshanting New Chemical Reagent Factory, China); phosphoric acid (Beijing Chemical Plant, China); acetic acid (Beijing Chemical Plant, China); boric acid (Beijing Chemical Plant, China); sodium hydroxide (Beijing Chemical Plant); nitric acid (Beijing Chemical Plant, China). The reagents used are analytical pure, and water is deionized water.
Cadmium standard solution ( $1 \mathrm{mg} / \mathrm{mL}): 0.20314 \mathrm{~g}$ $\mathrm{CdCl}_{2} \cdot 2.5 \mathrm{H}_{2} \mathrm{O}$ was weighed and placed to a beaker, dissolved in deionized water, transferred into $100 \mathrm{~mL}$ volumetric flask and diluted to the mark with deionized water.

Buffer solution ( $\mathrm{pH}=5.0)$ : In $100 \mathrm{~mL}$ tri-acid (all the concentrations of phosphoric acid, acetic acid and boric acid were $0.04 \mathrm{~mol} / \mathrm{L}), 35.0 \mathrm{~mL}$ of $0.20 \mathrm{~mol} / \mathrm{L} \mathrm{NaOH}$ solution was added.

\section{Experimental method}

\section{Preparation of SBA-15}

The specific method of hydrothermal synthesis of SBA15 was as follows: $2 \mathrm{~g} \mathrm{P123}$ tri-block copolymer template was dissolved in $15 \mathrm{~g}$ deionized water and $60 \mathrm{~g} 2 \mathrm{~mol} / \mathrm{L}$ hydrochloric acid solution and stirred, and $4.25 \mathrm{~g}$ TEOS was gradually added to the mixed solution. And at the constant temperature of $40^{\circ} \mathrm{C}$, continuous stirring was made for $24 \mathrm{~h}$. Then, the mixed solution was added to a reactor and continuously crystallized for $48 \mathrm{~h}$ at $100{ }^{\circ} \mathrm{C}$. After it, cooling, washing, filtering and room temperature drying were carried on, white powder was obtained and calcined at $550{ }^{\circ} \mathrm{C}$ for $24 \mathrm{~h}$ in a muffle furnace. After the template was removed successfully, white powder SBA-15 mesoporous molecular sieve was obtained (Zhai et al. 2013).

\section{Study on Cd(II) adsorption by nanomesoporous SBA-15}

The effect of $\mathrm{pH}$ on the adsorption of $\mathrm{Cd}^{2+}$ Eight portions of $20 \mathrm{~mL}$ of $\mathrm{Cd}^{2+}$ concentration $2.0 \mathrm{mg} / \mathrm{mL}$ working solution were taken out and placed in eight $100-\mathrm{mL}$ beakers. Five milliliters of $\mathrm{pH}$ 1.0, 2.0, 3.0, 4.0, 4.5, 5.0, 5.5, 6.0 tri-acid (phosphoric acid, acetic acid, boric acid)- $\mathrm{NaOH}$ buffer solution was added, respectively, to adjust $\mathrm{pH}$, and $15 \mathrm{~mL}$ deionized water was added to maintain $40 \mathrm{~mL}$ volume. $0.10 \mathrm{~g}$ of SBA-15 was weighed in turn, added to the above solutions and was continuously stirred at room temperature for $40 \mathrm{~min}$. Then, filtration was made. The content of $\mathrm{Cd}^{2+}$ in filtrate was determined by spectrophotometric method of 2-(5-bromo-2-pyridylazo)-5-diethylaminophenol (5-Br-PADAP) (Luo and Lin 2003), and the adsorption rate and adsorption capacity were calculated.

The effect of adsorbent dosage on the adsorption of $\mathrm{Cd}^{2+}$ Four portions of $20 \mathrm{~mL}$ of $\mathrm{Cd}^{2+}$ concentration $2.0 \mathrm{mg} / \mathrm{mL}$ working solution were taken out and placed in four $100-\mathrm{mL}$ beakers. Five milliliters of pH 1.0, 2.0, 3.0, 4.0, 4.5, 5.0, 5.5, 6.0 tri-acid (phosphoric acid, acetic acid, boric acid)- $\mathrm{NaOH}$ buffer solution was added, respectively, to adjust to the optimum $\mathrm{pH}$, and $15 \mathrm{~mL}$ deionized water was added to maintain $40 \mathrm{~mL}$ volume. $0.050,0.10,0.15,0.20 \mathrm{~g}$ of SBA-15 were, respectively, weighed, added to the above samples, and were continuously stirred at room temperature $25^{\circ} \mathrm{C}$ for $40 \mathrm{~min}$. 
Then, filtration and drying was made. The filtrate was taken and determination of $\mathrm{Cd}^{2+}$ content in filtrate was carried out by spectrophotometry with 2-(5-bromo-2-pyridylazo)-5diethylaminophenol(5-Br-PADAP) (Luo and Lin 2003), and the adsorption rate and adsorption capacity were calculated.

The effect of temperature on the adsorption of $\mathrm{Cd}^{2+}$ Four portions of $20 \mathrm{~mL}$ of $\mathrm{Cd}^{2+}$ concentration $2.0 \mathrm{mg} / \mathrm{mL}$ working solution were taken out and placed in four $100-\mathrm{mL}$ beakers. $5 \mathrm{~mL}$ of $\mathrm{pH}=5.0$ tri-acid (phosphoric acid, acetic acid, boric acid)- $\mathrm{NaOH}$ buffer solution were added, respectively, to adjust to the optimum $\mathrm{pH}$, and $15 \mathrm{~mL}$ deionized water were added to maintain $40 \mathrm{~mL}$ volume. $0.10 \mathrm{~g}$ of SBA-15 adsorbent were weighed, respectively, added to the above samples, and were stirred at $4,25,35,45^{\circ} \mathrm{C}$ for $40 \mathrm{~min}$. Filtration was made. The filtrate was taken and determination of $\mathrm{Cd}^{2+}$ content in filtrate was carried out by spectrophotometry with 2-(5-bromo-2-pyridylazo)-5-diethylaminophenol (5-Br-PADAP) (Luo and Lin 2003), and the adsorption rate and adsorption capacity were calculated.

The effect of initial concentration on the adsorption of $\mathrm{Cd}^{2+}$ Six portions of $20 \mathrm{~mL}$ of $\mathrm{Cd}^{2+}$ concentration $1.0,1.6$, 2.0, 2.4, 3.0, $4.0 \mathrm{mg} / \mathrm{mL}$ working solution were taken out and placed in six 100-mL beakers. Five milliliters $\mathrm{pH}=5.0$ tri-acid (phosphoric acid, acetic acid, boric acid)- $\mathrm{NaOH}$ buffer solution was added, respectively, to adjust to the optimum $\mathrm{pH}$, and $15 \mathrm{~mL}$ deionized water was added to maintain $40 \mathrm{~mL}$ volume. $0.10 \mathrm{~g}$ of SBA-15 adsorbent were weighed, respectively, added to the above samples, and were stirred at room temperature $25^{\circ} \mathrm{C}$ for $40 \mathrm{~min}$. Filtration was made. A suitable filtrate was taken and determination of $\mathrm{Cd}^{2+}$ content in filtrate was carried out by spectrophotometry with 2-(5-bromo-2-pyridylazo)-5-diethylaminophenol (5-Br-PAD AP) (Luo and Lin 2003), and the adsorption rate and adsorption capacity was calculated.

The effect of contact time on the adsorption of $\mathrm{Cd}^{2+} \mathrm{Six}$ portions of $20 \mathrm{~mL}$ of $\mathrm{Cd}^{2+}$ concentration $2.0 \mathrm{mg} / \mathrm{mL}$ working solutions were taken out and placed in six 100-mL beakers. $5 \mathrm{~mL} \mathrm{pH}=5.0$ tri-acid (phosphoric acid, acetic acid, boric acid)- $\mathrm{NaOH}$ buffer solution was added, respectively, to adjust to the optimum $\mathrm{pH}$, and $15 \mathrm{~mL}$ deionized water was added to maintain $40 \mathrm{~mL}$ volume. $0.10 \mathrm{~g}$ of SBA-15 adsorbent were weighed, respectively, added to the above samples, and were stirred at room temperature $25{ }^{\circ} \mathrm{C}$ for 10, 20, 30, 40, 50, 60 min. Filtration was made. A suitable filtrate was taken and determination of $\mathrm{Cd}^{2+}$ content in filtrate was carried out by spectrophotometry with 2-(5-bromo2-pyridylazo)-5-diethylaminophenol (5-Br-PAD AP) (Luo and Lin 2003), and the adsorption rate and adsorption capacity were calculated.

\section{Study on desorption}

$20 \mathrm{~mL}$ of $\mathrm{Cd}^{2+}$ concentration $2.0 \mathrm{mg} / \mathrm{mL}$ working solution were taken out and placed in a $100-\mathrm{mL}$ beaker. Five milliliters $\mathrm{pH}=5.0$ tri-acid (phosphoric acid, acetic acid, boric acid)$\mathrm{NaOH}$ buffer solution was added, to adjust to the optimum $\mathrm{pH}$, and $15 \mathrm{~mL}$ deionized water was added to maintain $40 \mathrm{~mL}$ volume. $0.10 \mathrm{~g}$ of SBA-15 adsorbent were weighed, added to the above sample, stirred at room temperature $25^{\circ} \mathrm{C}$ for $40 \mathrm{~min}$, and filtrated. The solids obtained after filtration were added to a $50-\mathrm{mL}$ beaker, and $10 \mathrm{~mL}$ of nitric acid or hydrochloric acid was added, respectively. It was desorbed at $25^{\circ} \mathrm{C}$ for $2,4,6,8,10,12 \mathrm{~h}$. After the desorption, filtration was carried out. A suitable filtrate was taken, and determination of $\mathrm{Cd}^{2+}$ content in filtrate was carried out by spectrophotometry with 2-(5-bromo-2-pyridylazo)-5-diethylaminophenol (5-Br-PADAP) (Luo and Lin 2003), and the desorption rate was calculated.

\section{Principles: adsorption kinetics, isotherm, thermodynamics}

Study on adsorption kinetics In this study, the adsorption mechanism of $\mathrm{Cd}^{2+}$ by SBA-15 was studied by using the adsorption kinetic models commonly used at present, namely quasi-first-order kinetic and quasi-second-order kinetic adsorption rate models.

Quasi-first-order adsorption kinetic model The quasi-firstorder kinetic adsorption equation, namely the Lagrange equation, can be expressed as (Lagergren 1898):

$\mathrm{d} q / \mathrm{d} t=k_{1}\left(q_{\mathrm{e}}-q\right)$

where $q_{\mathrm{e}}$ is equilibrium adsorption capacity, $\mathrm{mg} / \mathrm{g} ; q$ is the amount of adsorption at a certain time, $\mathrm{mg} / \mathrm{g}$; and $k_{1}$ is the rate constant of adsorption kinetics.

The formula (1) can be integrated from $t=0$ to $t>0 \quad(q=0$ to $q>0$ ), and the form of a straight line of the equation can be obtained:

$\ln \left(q_{\mathrm{e}}-q_{t}\right)=\ln \left(q_{\mathrm{e}}\right)-k_{1} t / 2.303$

Quasi-second-order adsorption kinetic model McKay equation can be used to describe the second-order model of adsorption kinetics. Its form can be expressed as (McKay and Ho 1999):

$\mathrm{d} q_{t} / \mathrm{d} t=k_{2}\left(q_{\mathrm{e}}-q_{t}\right)^{2}$

where $q_{\mathrm{e}}$ is equilibrium adsorption capacity, $\mathrm{mg} / \mathrm{g} ; q$ is the amount of adsorption at a certain time, $\mathrm{mg} / \mathrm{g}$; and $k_{2}$ is the rate constant of adsorption kinetics.

The formula (3) can be integrated from $t=0$ to $t>0(q=0$ to $q>0$ ), and the form of a straight line of the equation can be obtained:

$t / q_{t}=1 /\left(k_{2} q_{\mathrm{e}}^{2}\right)+\left(1 / q_{\mathrm{e}}\right) t$ 


\section{Study on adsorption isotherm}

Langmuir and Freunlich isothermal model equations can be used to calculate the parameters of related adsorption properties. The Langmuir adsorption isotherm formula is (Langmuir 1918):

$q_{\mathrm{e}}=K_{\mathrm{L}} q_{\mathrm{m}} C_{\mathrm{e}} /\left(1+K_{\mathrm{L}} C_{\mathrm{e}}\right)$

$1 / q_{\mathrm{e}}=1 / q_{\mathrm{m}}+1 /\left(K_{\mathrm{L}} C_{\mathrm{e}} q_{\mathrm{m}}\right)$

where the equilibrium loading capacity of adsorbent can be expressed by $q_{\mathrm{e}}(\mathrm{mg} / \mathrm{g}), q_{\mathrm{m}}(\mathrm{mg} / \mathrm{g})$ is the maximum adsorption capacity of monolayer covering, $C_{\mathrm{e}}(\mathrm{mg} / \mathrm{L})$ is the equilibrium concentration of adsorbent, and $K_{\mathrm{L}}(\mathrm{L} / \mathrm{mg})$ is the adsorption equilibrium constant.

Freundlich-type adsorption isotherm is an empirical adsorption equilibrium model based on adsorption of adsorbent on multiphase surface. The formula is (Freundlich 1906):

$q_{\mathrm{e}}=\ln K_{\mathrm{F}}+(1 / n) \ln C_{\mathrm{e}}$

In the formula, $q_{\mathrm{e}}$ is the adsorption amount when adsorption reaches equilibrium, $\mathrm{mg} / \mathrm{g} ; C_{\mathrm{e}}$ is the concentration of adsorbate in solution at adsorption equilibrium, $\mathrm{mg} / \mathrm{L}$; and $K_{\mathrm{F}}$ is the constant related to adsorption capacity and adsorption strength under Freundlich model. $1 / n$ is the Freundlich constant. The $K_{\mathrm{F}}, n$ value can very well reflect the adsorption performance choiceness of the adsorbent. The Freundlich adsorption isotherm can be obtained by plotting using $\ln q_{\mathrm{e}}$ versus $\ln C_{\mathrm{e}}$ under different temperature conditions.

When the Freundlich index is $n<0.5$, the adsorption is difficult to carry out. When $n<1$, the adsorption is nonpreferential type one. When $n=1$, the adsorption is linear. At the time of $n>1$, the adsorption is preferential one. That is, the molecular affinity of adsorbate molecules and solid adsorbent decreases with the increase in temperature, and the isotherm slope decreases with the increase in adsorbate concentration in the fluid.

\section{Study on adsorption thermodynamics}

Through the calculation of adsorption thermodynamics, the trend, degree and driving force of adsorption process can be successfully simulated. The thermokinetic characteristics of solute adsorption are usually be expressed by using the following equations (Gerel et al. 2007):

$K_{\mathrm{c}}=Q_{\mathrm{e}} / C_{\mathrm{e}}$

$\Delta G^{0}=-R T \ln K_{\mathrm{c}}$

$\ln K_{\mathrm{c}}=-\Delta G^{0} /(R T)=-\Delta H^{0} /(R T)+\Delta S^{0} / R$
In the formula, $K_{\mathrm{c}}$ is the equilibrium constant, $Q_{\mathrm{e}}(\mathrm{mg} / \mathrm{g})$ is the equilibrium adsorption capacity, $C_{\mathrm{e}}(\mathrm{mg} / \mathrm{mL})$ is the equilibrium adsorption concentration, $\Delta G^{0}(\mathrm{~kJ} / \mathrm{mol})$ is the free energy variation value of the adsorption process, the gas constant is $R=8.314 \mathrm{~J} /(\mathrm{mol} \mathrm{K}), T$ is the thermodynamic absolute temperature $(\mathrm{K}), \Delta H^{0}(\mathrm{~kJ} / \mathrm{mol})$ is the enthalpy change value of adsorption process, and $\Delta S^{0}[\mathrm{~J} /(\mathrm{mol} \mathrm{K})]$ is entropy variable value. The adsorption thermodynamic curve was done with $1 / T$ as the transverse coordinate and $\ln K_{\mathrm{c}}$ as the vertical coordinate.

\section{Instruments and characterization}

A 722S spectrophotometer (Shanghai Lengguang Technology Co., Ltd., China) was used in the determination of cadmium content. D5005 type X-ray diffractometer (XRD, German Siemens Company) was used to carry out powder X-ray diffraction experiment. $\mathrm{Cu}-\mathrm{K} \alpha$ target and $\lambda=1.5418 \AA$ was used. The operating voltage and current was $50 \mathrm{kV}, 150 \mathrm{~mA}$, respectively. The scanning range and the step length was $0.4^{\circ}-10^{\circ}, 0.02^{\circ}$, respectively. The high-resolution transmission electron microscopy (HRTEM) photo-experiment was carried out in FEI Tecnai G2 F20 field emission TEM to observe the structure morphology of the sample. The working voltage was $200 \mathrm{kV}$. The scanning electron microscope (SEM) photograph was determined and obtained by Philips XL30 field emission SEM to observe the size and morphology of the sample, and the operating voltage was $20 \mathrm{kV}$. The specific surface area, pore volume and pore size distribution of the sample were measured by low-temperature nitrogen adsorption-desorption experiment and were measured by ASAP 2020 V3.01H adsorption analyzer made by American Micromerities Company at $77 \mathrm{~K}$ liquid nitrogen. Before determination, the sample was activated at vacuum at $363 \mathrm{~K}$ for $12 \mathrm{~h}$. The data were calculated by using the Bdb (Broekhoff and de Boer) method (Brokhoff and Boer 1968). The pore size distribution was measured by BJH (Barrett-Joyner-Halenda) method (Brunauer et al. 1938) and the specific surface area was determined by BET (Brunner-Emmett-Teller) method (Barrett et al. 1951).

\section{Results and discussion}

\section{Sample characterization}

The powder XRD pattern of the sample SBA-15 is shown in Fig. 1. By observing the XRD diffraction peaks of the sample, it is found that these peaks are in good agreement with those reported in the literature (Zhai et al. 2013) and have the typical characteristic peaks of SBA-15. Therefore, the prepared sample is SBA-15. Figure 2 is transmission 


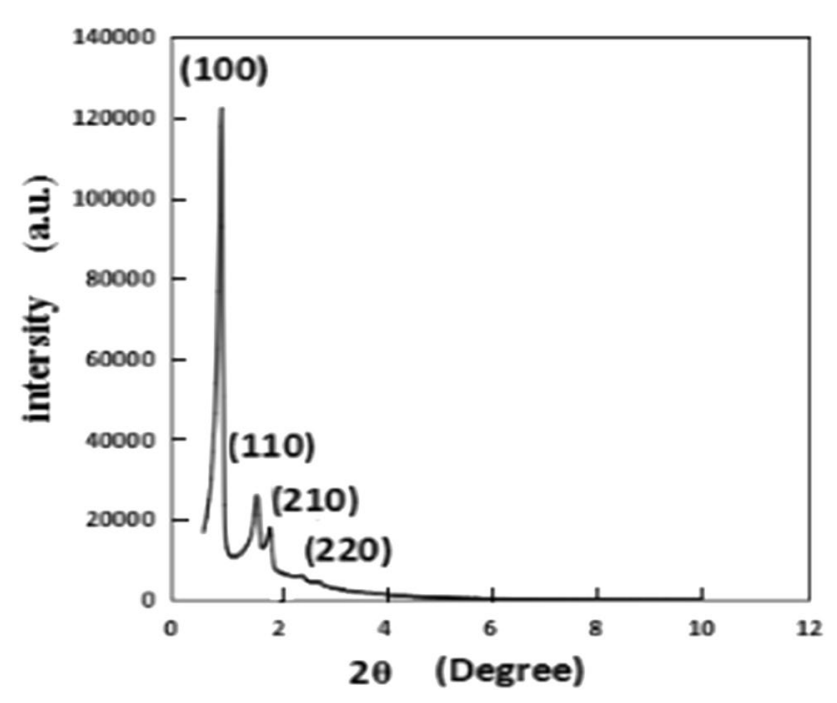

Fig. 1 XRD pattern of sample SBA-15

electron microscope (TEM) diagrams of SBA-15 obtained from different angles, figure (A) is a high-resolution TEM photograph taken by SBA-15 perpendicular to the channels, and figure (B) is a TEM photograph taken from a direction parallel to the holes. It can be seen by TEM picture that the pore stripes are clear and ordered, which indicates that the prepared SBA-15 material is a typical mesoporous material. TEM images show that the SBA 15 molecular sieve has a planar hexagonal mesoporous structure with a pore size of $9.4 \pm 0.1 \mathrm{~nm}$. Figure 3 shows the SEM photograph of the sample SBA-15. It can be seen from the SEM photograph that the appearance of the sample is very regular and presents wheat spike shape, with a size of $333 \pm 10 \mathrm{~nm}$.

Figure 4 gives the low-temperature nitrogen adsorption-desorption isotherm of SBA-15 sample at $77 \mathrm{~K}$. According to the classification of IUPAC, the adsorption isotherm of SBA-15 belongs to IV type adsorption isotherm. In the isotherm, the $\mathrm{H}$ 1-hysteresis ring emerges, showing that

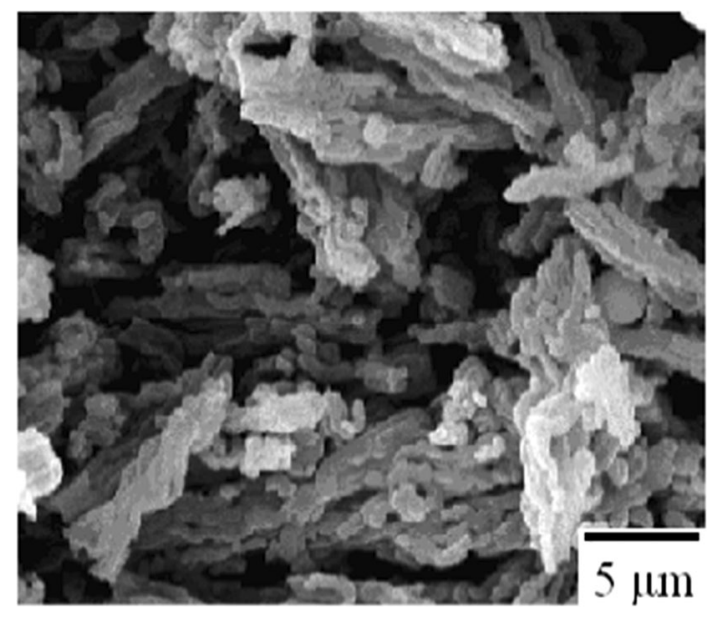

Fig. 3 SEM images of SBA-15 sample

the holes are cylindrical pores. There is an obvious branch of adsorption and desorption in the characteristic hysteresis ring of nitrogen adsorption-desorption isotherm of the prepared SBA-15. With the change of pressure, nitrogen molecules gradually transfer to multi molecular adsorption by monolayer dispersion. Over the range of relative partial pressure $\left(p / p_{0}\right) 0-0.685$, with the increase in the relative partial pressure, the molecules are adsorbed on the outer surface of mesopores by monolayer to multilayer, and the adsorbed nitrogen volume increases. Because the capillary condensation begins on the annular adsorption film on the hole wall, and the desorption begins from the spherical meniscus of the orifice, thus a hysteresis ring in the adsorption-desorption isotherm often exists. When the relative partial pressure reaches 0.685 , because of the phenomenon of capillary condensation, sudden jump phenomena appear in the adsorption branch and desorption branch of the adsorption-desorption isotherms. When the relative partial pressure reaches 0.872 ,
Fig. 2 TEM images of SBA-15 sample; A taken on perpendicular to pore direction and $\mathbf{B}$ taken on parallel to pore direction

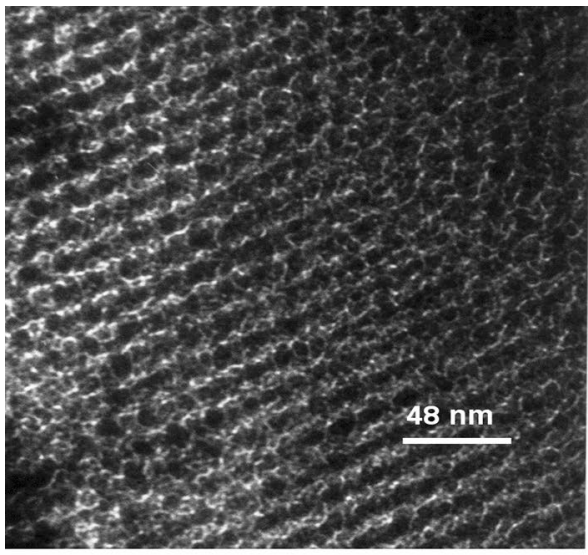

(A)

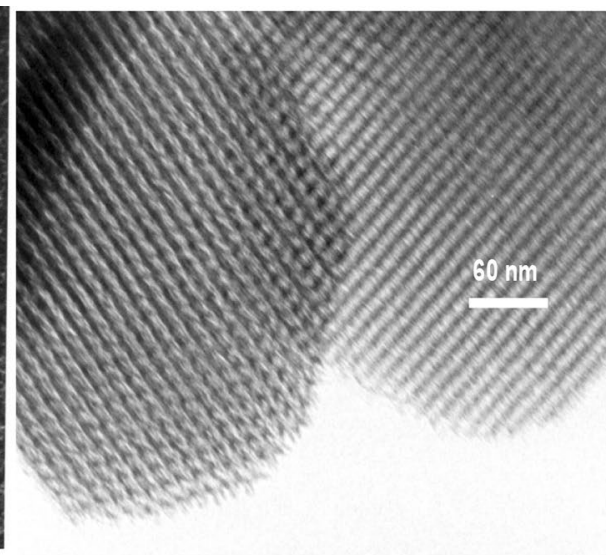

(B)

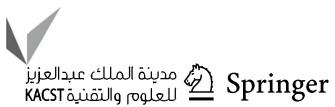




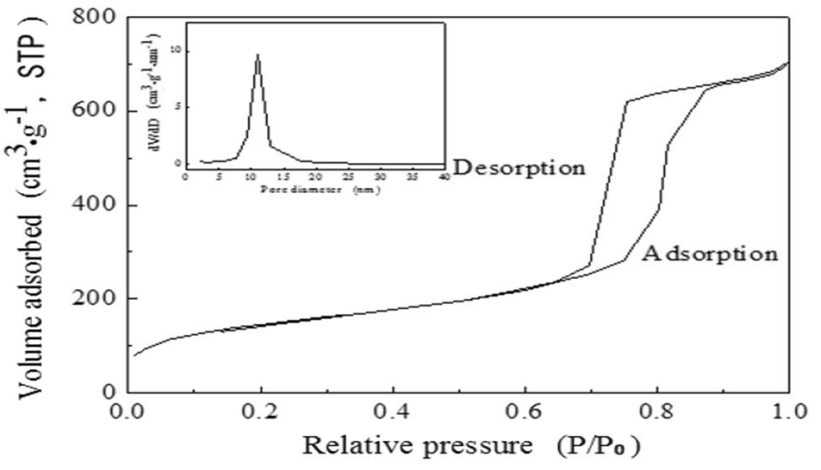

Fig. 4 Nitrogen adsorption-desorption pattern of SBA-15 sample and pore size distribution pattern

the desorption and adsorption curves on the isothermal diagram re-coincide, indicating that the hysteresis of $\mathrm{N}_{2}$ desorption disappears and the filled gas is filled with mesoporous channels of molecular sieve. The phenomenon of capillary condensation will gradually form on the surface of the material, because of the change of pressure, the phenomenon of condensation will change inversely, which will make the hysteresis of desorption branch disappear. The pore size distribution of adsorbent SBA-15 is as shown in Fig. 4. It can be seen from the diagram that the pore size distribution of the sample is relatively narrow and the most probable pore size is $11.02 \mathrm{~nm}$. Table 1 lists the basic physicochemical properties of structural characterization of SBA- 15 .

\section{Influence of the adsorption conditions on adsorption efficiency}

\section{Effect of the initial pH value of solution on $\mathrm{Cd}^{2+}$ adsorption}

Solution $\mathrm{pH}$ is one of the most important factors affecting the adsorption rate of adsorbate and the capacity of adsorbent for adsorbate. The efficiency of adsorption is dependent on the solution $\mathrm{pH}$ value, because variation in $\mathrm{pH}$ leads to the variation in the degree of ionization of the adsorptive molecule and the surface properties of adsorbent. The effect of the initial solution $\mathrm{pH}$ value on the adsorption rate and adsorption capacity of $\mathrm{Cd}^{2+}$ (Fig. 5) shows that with

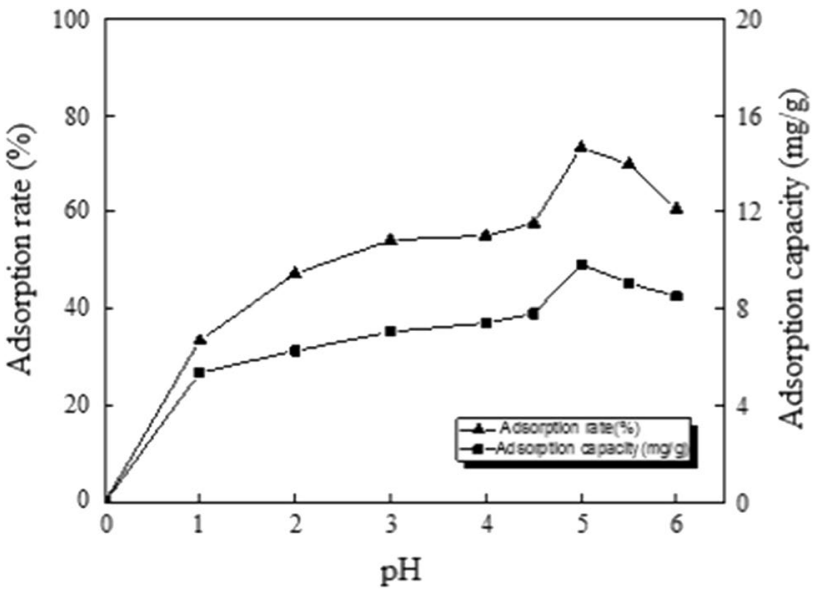

Fig. 5 Effect of $\mathrm{pH}$ on cadmium(II) adsorption; $\mathrm{m}(\mathrm{SBA}-15)=0.10 \mathrm{~g}$, $t=40 \mathrm{~min}, \mathrm{C}_{\mathrm{Cd}^{2+}}=1.0 \mathrm{mg} / \mathrm{mL}, T=25^{\circ} \mathrm{C}$

the increase in $\mathrm{pH}$ value the adsorption rate and adsorption capacity of cadmium increase and reach the maximum values when $\mathrm{pH}$ is 5.0. Then it decreases with the increase in $\mathrm{pH}$ value. When the $\mathrm{pH}$ value is 5.0, the maximum adsorption rate and adsorption capacity are $73.28 \%$ and $9.84 \mathrm{mg} / \mathrm{g}$, respectively. The results show that the mesoporous SBA-15 molecular sieve can adsorb $\mathrm{Cd}^{2+}$ very well under the condition of weak acidity. Under the condition that the $\mathrm{pH}$ value is less than 5.0, the positive charge on the surface of SBA15 increases, so the adsorption capacity of $\mathrm{Cd}^{2+}$ is lower. However, when the $\mathrm{pH}$ value is greater than $5.0, \mathrm{Cd}^{2+}$ is hydrolyzed and the existence quantity of $\mathrm{Na}^{+}$is increased, which competes the adsorption sites on SBA- 15 surface with $\mathrm{Cd}^{2+}$, thus reducing the adsorption capacity of $\mathrm{Cd}^{2+}$.

\section{Effect of SBA-15 dosage on $\mathrm{Cd}^{2+}$ adsorption}

Figure 6 shows the relationship pattern of effect of the amount of adsorbent on the adsorption rate and the adsorption capacity of $\mathrm{Cd}^{2+}$. It can be seen that with the increase in the amount of adsorbent, the adsorption rate shows increase trend, reaching the maximum at $0.10 \mathrm{~g}$. The maximum adsorption rate was $73.28 \%$; then, the adsorption was in equilibrium. And the adsorption capacity increased first and reached the maximum at $0.10 \mathrm{~g}$. The maximum adsorption capacity was $9.84 \mathrm{mg} / \mathrm{g}$. After that, the adsorption was in

Table 1 Physicochemical properties of SBA-15 sample

\begin{tabular}{|c|c|c|c|c|c|c|}
\hline Sample & $\begin{array}{l}\text { Interplanar spacing } \\
d_{100}(\mathrm{~nm})\end{array}$ & $\begin{array}{l}\text { Unit cell parameter } \\
a_{0}(\mathrm{~nm})\end{array}$ & $\begin{array}{l}\text { Specific surface are } \\
\left(\mathrm{m}^{2} / \mathrm{g}\right)\end{array}$ & $\begin{array}{l}\text { Porous volume } \\
\left(\mathrm{cm}^{3} / \mathrm{g}\right)\end{array}$ & Pore size $(\mathrm{nm})$ & $\begin{array}{l}\text { Pore wall thickness } \\
(\mathrm{nm})\end{array}$ \\
\hline SBA-15 & 8.84 & 10.20 & 503 & 1.10 & 11.02 & 1.87 \\
\hline
\end{tabular}

Unit cell parameter $a_{0}=2 \times d_{100} / \sqrt{3}$; average pore diameter $D_{\mathrm{p}}=4 V_{\mathrm{mes}} / S_{\mathrm{BET}}$. Here, $V_{\mathrm{mes}}$ is mesoporous volume, $S_{\mathrm{BET}}$ is BET specific surface area, pore wall thickness $=a_{0}-D_{\mathrm{p}}$ 


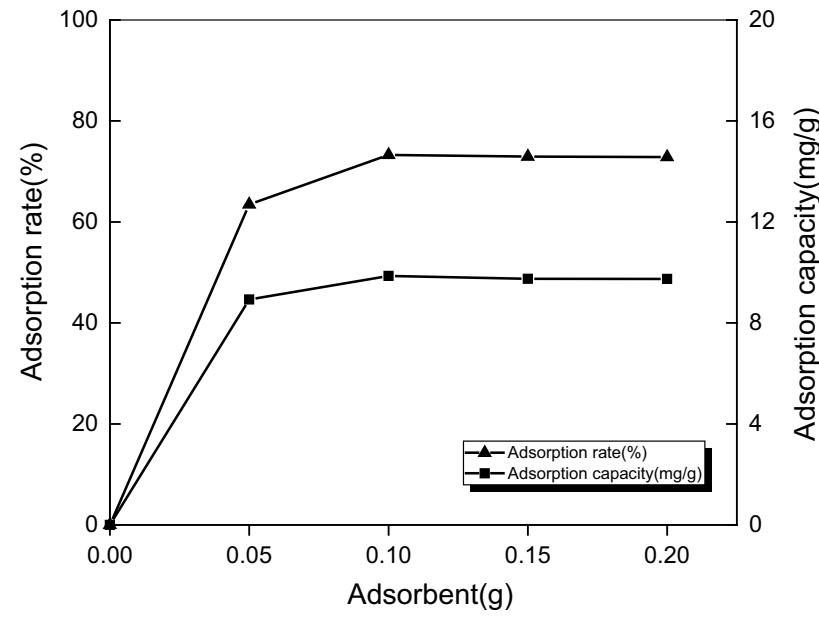

Fig. 6 Effect of adsorbent dosage on cadmium(II) adsorption; $\mathrm{pH}=5.0, \mathrm{C}_{\mathrm{Cd}^{2+}}=1.0 \mathrm{mg} / \mathrm{mL}, t=40 \mathrm{~min}, T=25^{\circ} \mathrm{C}$

equilibrium, indicating that the adsorption sites provided by SBA-15 increased with the increase in the amount of adsorbent, which made the competition of $\mathrm{Cd}^{2+}$ on the surface of adsorbent reduce and the adsorption capacity was decreased. Therefore, the optimum amount of adsorbent selected was $0.10 \mathrm{~g}$.

\section{Effect of temperature on the adsorption of $\mathrm{Cd}^{2+}$}

Figure 7 displays the curve of the relationship between temperature and the adsorption rate of cadmium as well as temperature and adsorption capacity. It can be seen from the figure that the adsorption rate and adsorption capacity increase first and then decrease with the increase in temperature. At a room temperature of $25^{\circ} \mathrm{C}$, the adsorption efficiency is

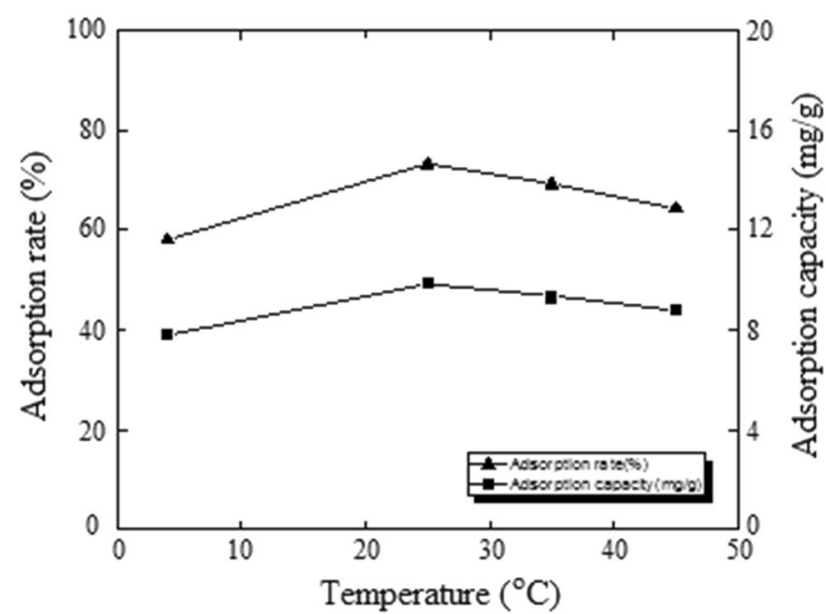

Fig. 7 Effect of temperature on cadmium adsorption; m(SBA$15)=0.10 \mathrm{~g}, t=40 \mathrm{~min}, \mathrm{pH}=5.0, \mathrm{C}_{\mathrm{Cd}^{2+}}=1.0 \mathrm{mg} / \mathrm{mL}$ the best, and the maximum adsorption rate and adsorption capacity are $73.28 \%$ and $9.84 \mathrm{mg} / \mathrm{g}$, respectively. The relationship between temperature and cadmium adsorption effect shows this trend, which is because SBA-15 adsorption $\mathrm{Cd}^{2+}$ is physical adsorption and adsorption process is endothermic at $4-25^{\circ} \mathrm{C}$. At $25-45^{\circ} \mathrm{C}$, it is chemisorption and the adsorption process is exothermic.

\section{Effect of the initial concentration of $\mathrm{Cd}^{2+}$ on adsorption effect}

Figure 8 is a diagram of the effect of initial concentration of $\mathrm{Cd}^{2+}$ on the adsorption rate and adsorption capacity of $\mathrm{Cd}^{2+}$. It can be seen from the diagram that with the increase in the initial concentration of $\mathrm{Cd}^{2+}$ the adsorption rate and adsorption capacity showed the same trend, gradually increased in the range of $0-1.0 \mathrm{mg} / \mathrm{mL}$, reached the maxima at $1.0 \mathrm{mg} /$ $\mathrm{mL}$, and then decreased gradually. Therefore, synthetically considering the adsorption rate and adsorption capacity, the initial concentration of $\mathrm{Cd}^{2+}$ selected is $1.0 \mathrm{mg} / \mathrm{mL}$. At this time, the maximum adsorption rate is $73.28 \%$ and the maximum adsorption capacity is $9.84 \mathrm{mg} / \mathrm{g}$.

\section{Effect of contact time on the adsorption result of $\mathrm{Cd}^{2+}$}

Figure 9 is the relationship diagram of the effect of contact time on the adsorption rate and adsorption capacity of $\mathrm{Cd}^{2+}$. It can be seen from the diagram that with the increase in contact time, the adsorption rate and adsorption capacity showed the same trend. Both increased in the range of 0-40 min, reached the maxima at $40 \mathrm{~min}$, and reached equilibrium after $40 \mathrm{~min}$, indicating that the adsorption reached equilibrium at $40 \mathrm{~min}$ at contact time. The maximum

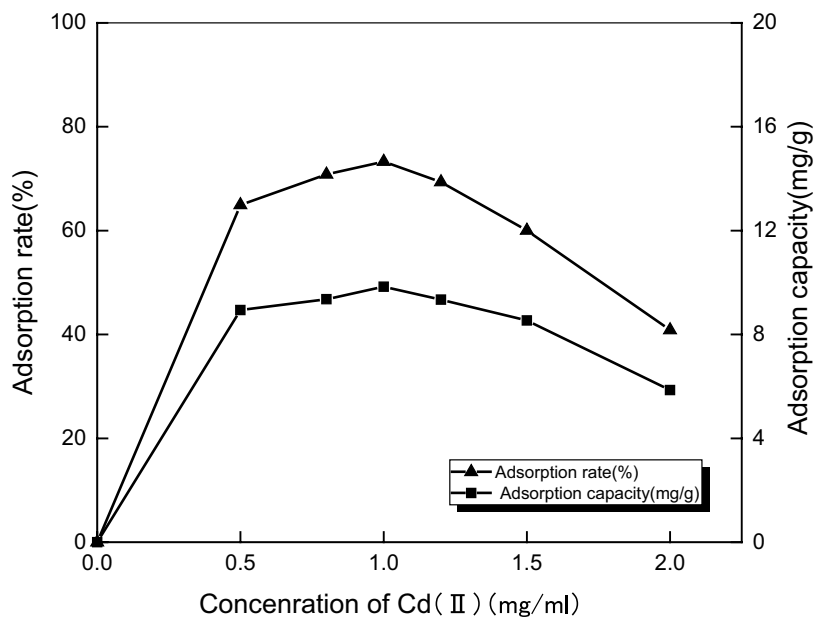

Fig. 8 Effect of the initial concentration of cadmium(II on adsorption result; $\mathrm{pH}=5.0, \mathrm{~m}(\mathrm{SBA}-15)=0.10 \mathrm{~g}, t=40 \mathrm{~min}, T=25^{\circ} \mathrm{C}$ 


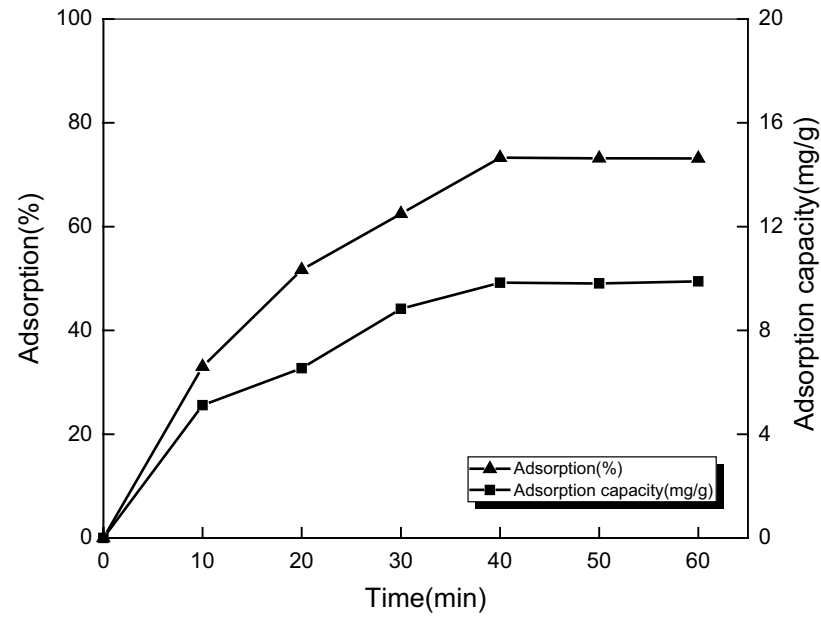

Fig. 9 Effect of contact time on cadmium adsorption; $\mathrm{pH}=5.0$, $\mathrm{m}(\mathrm{SBA}-15)=0.10 \mathrm{~g}, \mathrm{C}_{\mathrm{Cd}^{2+}}=1.0 \mathrm{mg} / \mathrm{mL}, T=25^{\circ} \mathrm{C}$

adsorption rate and adsorption capacity were $73.28 \%$ and $9.84 \mathrm{mg} / \mathrm{g}$, respectively.

To sum up, under the condition of $25 \pm 1{ }^{\circ} \mathrm{C}$ at room temperature, $\mathrm{pH}$ is 5.0 , the dosage of adsorbent SBA-15 is $0.10 \mathrm{mg} / \mathrm{mL}$ and the initial concentration of $\mathrm{Cd}^{2+}$ is $1.0 \mathrm{mg} /$ $\mathrm{mL}$, the volume is $40 \mathrm{~mL}$ system, the contact time is $40 \mathrm{~min}$, the adsorption rate of $\mathrm{Cd}^{2+}$ can reach $73.28 \%$. The adsorption capacity of $\mathrm{Cd}^{2+}$ is $9.84 \mathrm{mg} / \mathrm{g}$.

\section{Adsorption kinetics study}

Figures 10 and 11 are the result pattern obtained by fitting the experimental results of adsorption kinetics using quasifirst-order kinetic equation and quasi-second-order kinetic equation, and Table 2 shows the kinetic corresponding parameters. The results show that by fitting the quasi-firstorder kinetic equation and combining with the experimental data, the adsorption equilibrium capacities of different concentrations have big gaps with the experimental results. However, by using the quasi-second-order kinetic equation to fit, the calculated values of equilibrium adsorption capacity of each concentration are basically close to the experimental values, and the correlation coefficients are larger, so the kinetics of $\mathrm{Cd}^{2+}$ adsorption system by SBA- 15 accords with the quasi-second-order kinetic equation.

\section{Study on adsorption isotherm}

The Langmuir adsorption isotherm equation and Freundlich adsorption isotherm equation can very well fit the isotherm of SBA-15 adsorption $\mathrm{Cd}^{2+}$. Figures 12 and 13 are the results of linear fitting of the isotherm data of

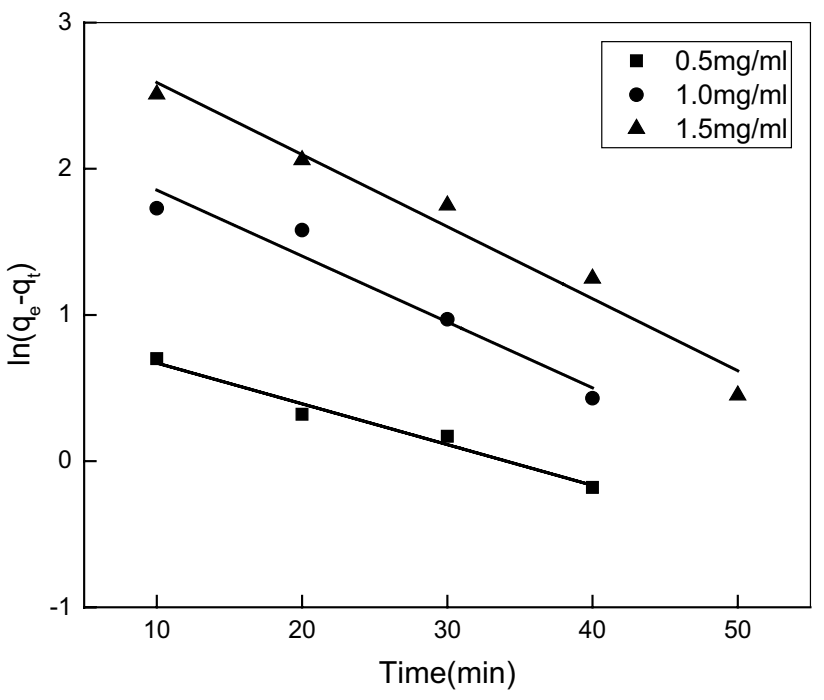

Fig. 10 Quasi-first-order kinetic fitting diagram

cadmium adsorption by SBA-15 with Langmuir adsorption isotherm equation and Freundlich adsorption isotherm equation, respectively. The calculated results of the corresponding parameters are shown in Tables 3 and 4. The maximum adsorption capacities obtained by the Langmuir adsorption isotherm equation are negative, which does not accord with the experimental results. The Freundlich adsorption isotherm equation fitting effect is better. The process of $\mathrm{Cd}(\mathrm{II})$ adsorption by SBA- 15 accords with the Freundlich adsorption model and is heterogeneous adsorption.

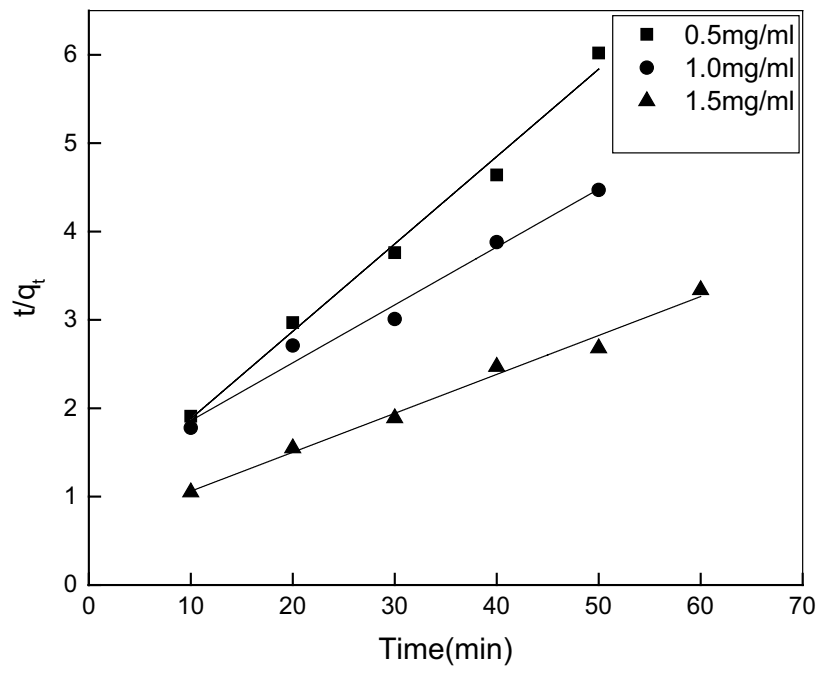

Fig. 11 Quasi-second-order kinetic fitting diagram 
Table 2 Kinetic parameters of SBA-15 adsorption $\mathrm{Cd}^{2+}$

\begin{tabular}{|c|c|c|c|c|c|c|c|}
\hline \multirow{2}{*}{$\begin{array}{l}\text { Concentra- } \\
\text { tion }(\mathrm{mg} / \\
\mathrm{mL})\end{array}$} & \multirow{2}{*}{$\begin{array}{l}\text { Adsorption capac- } \\
\text { ity measured } \\
(\mathrm{mg} / \mathrm{g})\end{array}$} & \multicolumn{3}{|c|}{$\begin{array}{l}\text { Quasi-first-order adsorption } \\
\text { kinetic equation }\end{array}$} & \multicolumn{3}{|c|}{$\begin{array}{l}\text { Quasi-second-order adsorption } \\
\text { kinetic equation }\end{array}$} \\
\hline & & $q_{\mathrm{e}}(\mathrm{mg} / \mathrm{g})$ & $k_{1}\left(\min ^{-1}\right)$ & $R_{1}$ & $q_{\mathrm{e}}(\mathrm{mg} / \mathrm{g})$ & $k_{2}(\mathrm{~g} / \mathrm{mg} \min )$ & $R_{2}$ \\
\hline 0.5 & 4.01 & 4.94 & 0.2634 & 0.9464 & 4.63 & 7.8543 & 0.9933 \\
\hline 1.0 & 9.84 & 11.60 & 0.0687 & 0.9571 & 10.08 & 10.5479 & 0.9913 \\
\hline 1.5 & 15.71 & 17.21 & 0.0981 & 0.9537 & 15.69 & 16.2371 & 0.9939 \\
\hline
\end{tabular}

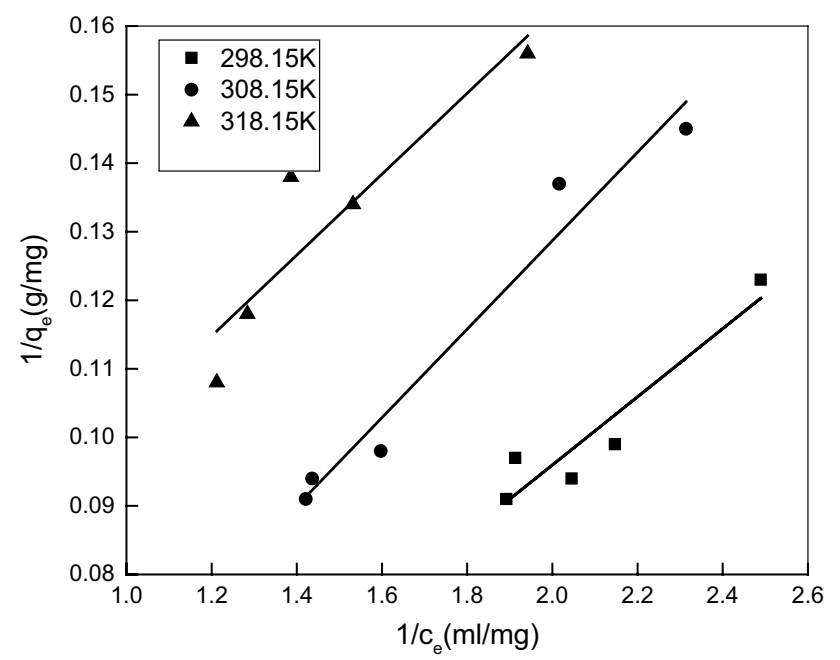

Fig. 12 Langmuir adsorption isotherm equation fitting diagram

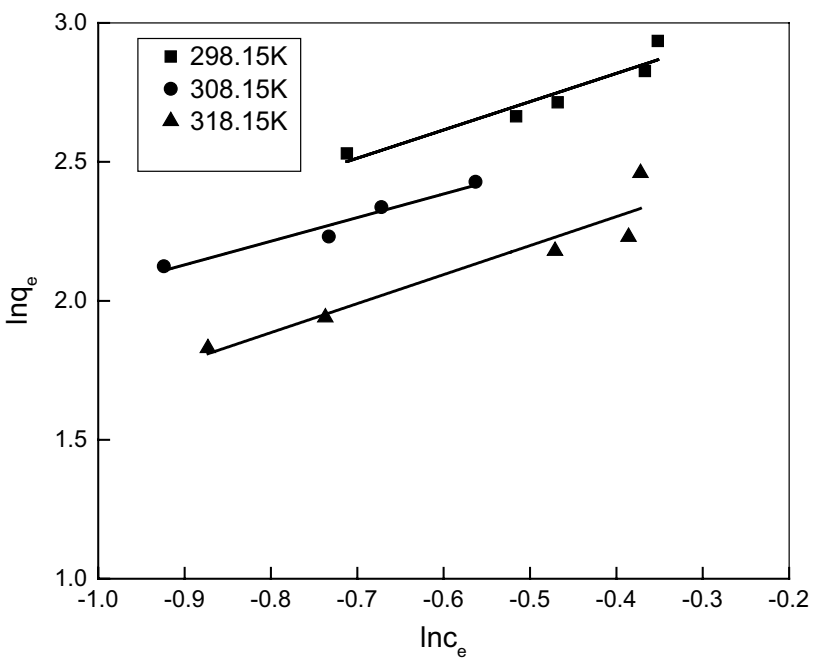

Fig. 13 Freundlich adsorption isotherm equation fitting diagram

\section{Adsorption thermodynamics study}

The adsorption thermodynamic curve equation of SBA-15 adsorption $\mathrm{Cd}^{2+}$ process is: $\ln \left(q_{\mathrm{e}} / c_{\mathrm{e}}\right)=4.8553 / T-11.695$, and the correlation coefficient $R=0.9923$. The linear effect is good (Fig. 14). The Gibbs free energy change, the adsorption enthalpy change and the adsorption entropy change in adsorption process can be calculated according to the corresponding formula (Gerel et al. 2007). It can be seen from Table 5 that the Gibbs free energy change $\Delta G^{0}<0$ of process of the adsorption of cadmium by SBA-15 indicates that the adsorption reaction takes place spontaneously. And $\Delta G^{0}$ is in the range of 0 to $-20 \mathrm{~kJ} / \mathrm{mol}$ (Gerel et al. 2007), so the adsorption of $\mathrm{Cd}^{2+}$ by SBA-15 is physical adsorption. From the calculation results, it can be seen that the absolute value of $\Delta G^{0}$ decreases when the temperature is higher, which indicates that the spontaneous trend of adsorption process will change with the change of temperature. When the temperature increases, it is unfavorable to the adsorption. For this adsorption, $\Delta H^{0}=-54.732 \mathrm{~kJ} /$ $\mathrm{mol}<0$, the reaction is exothermic. $\Delta S^{0}=-129.343 \mathrm{~J} /(\mathrm{mol} \mathrm{K})$, is negative, which indicates that the adsorption process is a process of entropy decreasing. After adsorption, the degree of freedom of adsorbate molecules is decreased and the order degree of molecular arrangement is increased.

\section{Desorption study}

The desorption curves of (SBA-15)-Cd that have already adsorbed $\mathrm{Cd}^{2+}$ were carried out by using $0.1 \mathrm{~mol} / \mathrm{L}$ nitric acid and hydrochloric acid, which can be seen from Fig. 15. The desorption rate increased with the increase in time in 2-10 h, reached its maximum at $10 \mathrm{~h}$, and began to decrease after $10 \mathrm{~h}$. Moreover, the desorption effect of nitric acid is better than that of hydrochloric acid. Therefore, compared nitric acid with hydrochloric acid, nitric acid is a better desorption agent with the maximum desorption rate of $65.56 \%$.
Table 3 Langmuir isothermal equation and data

\begin{tabular}{llclll}
\hline$T(\mathrm{~K})$ & Equation expression & $q_{\mathrm{m}}(\mathrm{mg} / \mathrm{g})$ & $K_{\mathrm{L}}$ & $R^{2}$ & $R$ \\
\hline 298.15 & $1 / q_{\mathrm{e}}=0.0264 / c_{\mathrm{e}}-0.0351$ & -26.154 & -1.247 & 0.9276 & 0.9631 \\
308.15 & $1 / q_{\mathrm{e}}=0.0634 / c_{\mathrm{e}}-0.1284$ & -7.341 & -1.836 & 0.9521 & 0.9758 \\
318.15 & $1 / q_{\mathrm{e}}=0.1357 / c_{\mathrm{e}}-0.2173$ & -4.157 & -1.535 & 0.9751 & 0.9875 \\
\hline
\end{tabular}


Table 4 Freundlich isothermal equation and data

\begin{tabular}{llllll}
\hline$T(\mathrm{~K})$ & Equation expression & $n$ & $K_{\mathrm{F}}$ & $R^{2}$ & $R$ \\
\hline 298.15 & $\ln q_{\mathrm{e}}=0.9634 \ln c_{\mathrm{e}}+3.0217$ & 1.0243 & 45.384 & 0.9958 & 0.9979 \\
308.15 & $\ln q_{\mathrm{e}}=1.4348 \ln c_{\mathrm{e}}+3.4871$ & 0.6875 & 33.537 & 0.9968 & 0.9984 \\
318.15 & $\ln q_{\mathrm{e}}=1.8371 \ln c_{\mathrm{e}}+3.3576$ & 0.5428 & 26.275 & 0.9952 & 0.9976 \\
\hline
\end{tabular}

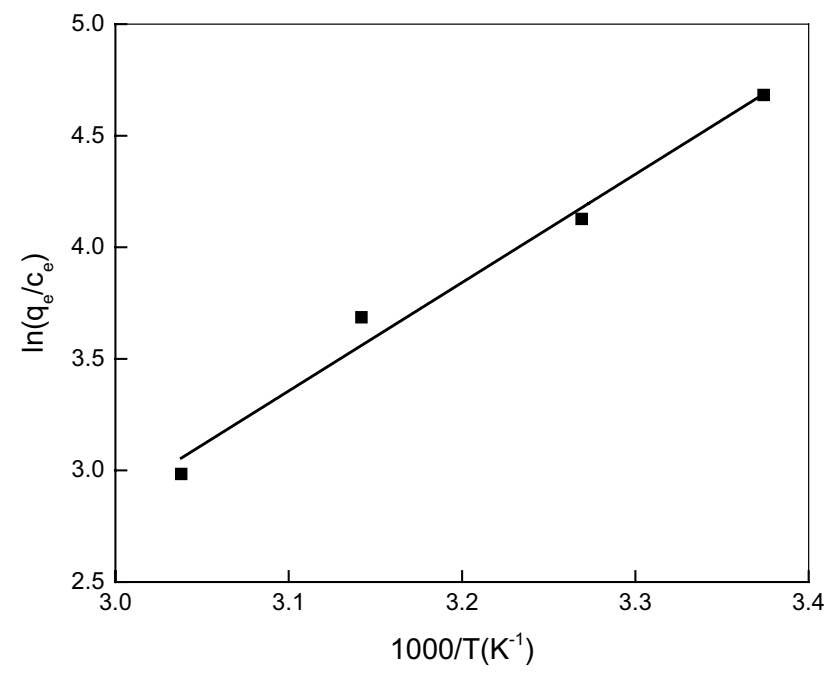

Fig. 14 Adsorption thermodynamic fitting diagram

Table 5 Adsorption thermodynamic data

\begin{tabular}{llll}
\hline$T(\mathrm{~K})$ & $\Delta G^{0}(\mathrm{~kJ} / \mathrm{mol})$ & $\Delta H^{0}(\mathrm{~kJ} / \mathrm{mol})$ & $\Delta S^{0}[\mathrm{~J} /(\mathrm{mol} \mathrm{K})]$ \\
\hline 298.15 & -13.214 & -54.732 & -129.343 \\
308.15 & -11.954 & & \\
318.15 & -9.847 & & \\
328.15 & -8.567 & & \\
\hline
\end{tabular}

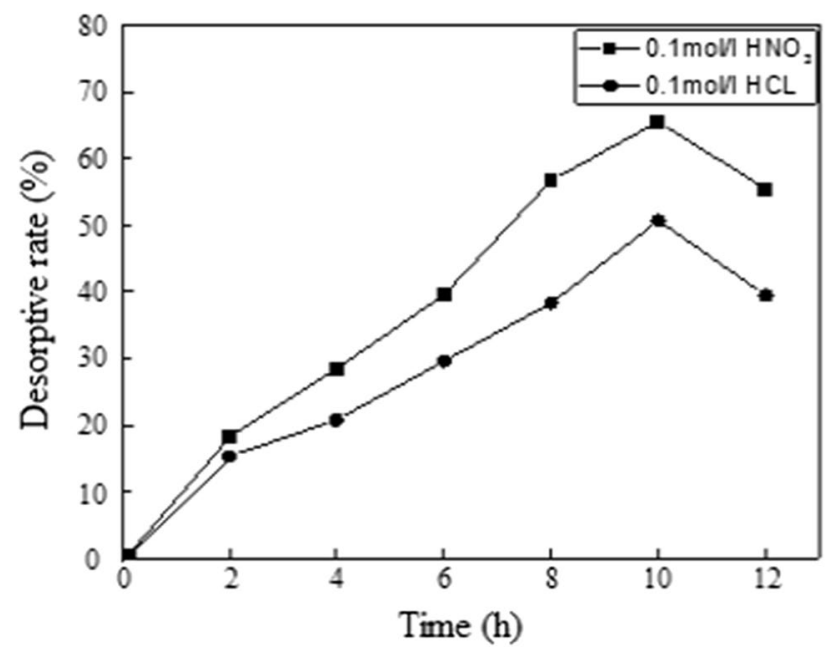

\section{Conclusions}

In this study, the optimized adsorption conditions, adsorption kinetic properties, adsorption isotherms, adsorption thermodynamic properties and desorption of SBA-15 for $\mathrm{Cd}^{2+}$ were studied using nanomesoporous SBA-15 molecular sieve as adsorbent. The following conclusions were drawn:

1. Under the condition of $25 \pm 1^{\circ} \mathrm{C}, \mathrm{pH}$ is 5.0 , the amount of adsorbent SBA-15 is $0.100 \mathrm{~g}$, the initial concentration of $\mathrm{Cd}^{2+}$ is $1.0 \mathrm{mg} / \mathrm{mL}$ and volume is $40 \mathrm{~mL}$ system, when the contact time is $40 \mathrm{~min}$, the adsorption rate of $\mathrm{Cd}^{2+}$ can reach $73.28 \%$ and the adsorption capacity is $9.84 \mathrm{mg} / \mathrm{g}$.

2. The results of adsorption kinetics showed that the adsorption of $\mathrm{Cd}^{2+}$ by SBA-15 is the quasi-second-order kinetic model.

3. SBA-15 adsorption $\mathrm{Cd}^{2+}$ process accords with Freundlich adsorption model. At $4-25{ }^{\circ} \mathrm{C}$, the adsorption of $\mathrm{Cd}^{2+}$ by SBA- 15 is physical adsorption and the adsorption process is endothermic. At $25-45^{\circ} \mathrm{C}$, it is chemisorption and the adsorption process is exothermic.

4. The adsorption thermodynamics study showed that the adsorption process of $\mathrm{Cd}^{2+}$ by SBA- 15 is spontaneous at $25-55{ }^{\circ} \mathrm{C}$ and the Gibbs free energy change $\Delta G^{0}<0$. At the same time, $\Delta H^{0}=-54.732 \mathrm{~kJ} / \mathrm{mol}$, $\Delta S^{0}=-129.343 \mathrm{~J} /(\mathrm{mol} \mathrm{K})$, the adsorption is an exothermic reaction, and the adsorption process is a physical adsorption process in which the entropy decreases.

5. The results of desorption study showed that $0.1 \mathrm{~mol} / \mathrm{L}$ nitric acid has better desorption effect on (SBA-15)-Cd, the optimum desorption time is $10 \mathrm{~h}$ and the maximum desorption rate is $65.56 \%$.

Acknowledgements The authors appreciate financial support from the Natural Science Foundation of Jilin Provincial Science and Technology Department from the Science and Technology Development Program of Jilin Province, China (Nos. 20180101180JC, 222180102051, KYC-JC-XM-2018-051).

\section{Compliance with ethical standards}

Conflict of interest No potential conflict of interest was reported by the author.

Open Access This article is distributed under the terms of the Creative Commons Attribution 4.0 International License (http://creativeco mmons.org/licenses/by/4.0/), which permits unrestricted use, distribution, and reproduction in any medium, provided you give appropriate credit to the original author(s) and the source, provide a link to the Creative Commons license, and indicate if changes were made.

Fig. 15 Relationship between desorption rate and time 


\section{References}

Barrett EP, Joyner LG, Halenda PP (1951) The determination of pore volume and area distributions in porous substances. I. Computation from nitrogen isotherms. J Am Chem Soc 73(1):373-380

Brokhoff JCP, Boer JHD (1968) Studies on pore systems in catalysts: XII. Pore distributions from the desorption branch of a nitrogen sorption isotherm in the case of cylindrical pores A. An analysis of the capillary evaporation process. J Catal 10(4):391-400

Brunauer S, Emmett PH, Teller E (1938) Adsorption of gases in multimolecular layers. J Am Chem Soc 60(2):309-319

Che RR (1993) Application of ion exchange method in treatment of wastewater containing cadmium. Ion Exch Adsorp 3:276-279

Clifford D, Subramonian S, Sorg T (1986) Removing dissolved inorganic contaminants from water. J Environ Sci Technol 20(11):1072-1080

Dai JC, Xiao ZJ, Wu HY (2001) Present situation and prospect of nanoporous materials. J Mineral 21(3):284-293

Dana E, Sayari A (2011) Adsorption of copper on amine-functionalized SBA-15 prepared by co-condensation: equilibrium properties. Chem Eng J 166:445-453

Deng JL, Hu XL, Guan P (2005) Membrane separation technology and its application in heavy metal wastewater treatment. Mater Rev 19(2):23-26

Freundlich H (1906) Over the adsorption in solution. J Phys Chem $57: 385-470$

Gerel O, Ozcan A, Ozcan AS, Gerel HF (2007) Preparation of activated carbon from a renewable bio-plant of Euphorbia Rigida, by $\mathrm{H}_{2} \mathrm{SO}_{4}$, activation and its adsorption behavior in aqueous solutions. Appl Surf Sci 253(11):4843-4852

Ghorbani M, Nowee SM, Ramezanian N (2016) A new nanostructured material amino functionalized mesoporous silica synthesized via co-condensation method for $\mathrm{Pb}(\mathrm{II})$ and $\mathrm{Ni}(\mathrm{II})$ ion sorption from aqueous solution. Hydrometallurgy 161:117-126

Jiang PJ, Lin ZY, Lin SB (2003) Preparation and research progress of mesoporous materials. Mater Rev 17(11):141-146
Lagergren S (1898) About the theory of the so-called adsorption of soluble substances. Kungliga Svenska Vetenskapsakadmius Hadndlingar 24(1):1-39

Langmuir I (1918) Adsorption of gases on plain surfaces of glass mica platinum. J Am Chem Soc 40:136-403

Li CH (1994) Present situation and improvement of cadmium cyanide wastewater treatment by ion exchange method in China. Ion Exch Adsorp 5:443-446

Lin YX, Sun LJ, Zhang WB (2003) Synthesis mechanism and application of mesoporous materials. Mater Rev 17(1):193-201

Liu SX, Huo JC, Li WG (2004) Progress in synthesis and preparation of porous materials. New Chem Mater 32(2):13-17

Luo YC, Lin C (2003) Spectrophotometric determination of trace cadmium in environmental water samples. Chin J Spectr Lab 20(5):790-792

McKay G, Ho YS (1999) Pseudo-second order model for sorption processes. Process Biochem 34(5):451-465

Pananyotova M (2000) Use of zeolite for cadmium removal from wastewater. Environ Lett 35(9):1591-1601

Zhai QZ, Wu YY, Wang XH (2013) Synthesis, characterization and sustaining controlled release effect of mesoporous SBA-15/Ramipril composite drug. J Incl Phenom Chem 76(3):300-303

Zhang RL (1997) Experimental study on the treatment of wastewater containing cadmium and arsenic from sulfuric acid production. Sulfuric Acid Ind 5:18-22

Zhu SF, Ni W, Zhang MJ (2001) Present situation and development of synthesis and application of mesoporous molecular sieves. J. Rock Mineral 25(4):24-28

Publisher's Note Springer Nature remains neutral with regard to jurisdictional claims in published maps and institutional affiliations. 